\title{
Alexis de Tocqueville, del Humanismo cívico al nacionalismo excluyente
}

\author{
Elisa Usategui Basozabal ${ }^{1}$ \\ Universidad del País Vasco/Euskal Erriko Unibertsitatea \\ elisa.usategui@ehu.eus
}

RESUMEN: La obra de Alexis de Tocqueville se dirige a hacer salir a los individuos del círculo de sus intereses privados, para que asuman su responsabilidad individual, política y social frente a la masa, escuchen a su deseo innato de libertad y hagan surgir de la igualdad, y, nunca contra ella, sino a través de ella, la libertad politica y social. Su amor a la libertad está siempre presente e impregna de sentido ético su pensamiento y su actividad política. De ahi deriva su profundo humanismo ante la situación de la población india y negra en tierras americanas y su oposición frontal a la esclavitud y a cualquier planteamiento racista, como algo contrario a los derechos naturales de los seres humanos.

Sin embargo, cuando el diputado Tocqueville toma la palabra, su objetivo primero no es ya la dignidad de los seres humanos, sino los intereses de Francia. Su posición ante la emancipación de los esclavos en los territorios franceses de ultramar, su actitud ante la conquista de Argelia, sus intervenciones en la Asamblea Nacional sobre política exterior nos muestran a un hombre de Estado imperialista, colonialista y racista. Anteriormente habia mostrado la ambivalencia de los fenómenos sociales, ahora aparece él mismo ambivalente e incoherente: el filósofo político versus el diputado en la Asamblea Nacional, el defensor de la dignidad humana versus el hombre remiso a asumir los derechos politicos y sociales de una parte de la humanidad, el moralista en América versus el imperialista y colonialista en Argelia y las colonias de ultramar.

Palabras clave: Tocqueville; esclavitud; colonialismo; Argelia; racismo.

\footnotetext{
${ }^{1}$ ORCID iD: https://orcid.org/0000-0002-6294-6315.
}

Copyright: (C) 2021 CSIC. Este es un artículo de acceso abierto distribuido bajo los términos de una licencia de uso y distribución Creative Commons Reconocimiento 4.0 Internacional (CC-BY 4.0) 


\section{Alexis de Tocqueville, from civic humanism to exclusionary nationalism}

ABSTRACT: The purpose of Alexis de Tocqueville's work was to draw individuals away from self-interest so that they could embrace individual civic, political and social responsibilities, and listen to their innate desire for freedom while allowing equality to emerge through - and not against-social and political freedom. His passion for freedom is always present and permeates his ideological and political activity. It is also at the root of his profound humanism in the face of the indigenous and African American condition in the Americas, and his outright opposition to slavery and any racist stance as notions that are contradictory to the natural rights of human beings.

However, when Alexis de Tocqueville took the floor as deputy, his primary concern was not the dignity of human beings but the interests of France. His stance towards the emancipation of slaves in French overseas territories, his attitude towards the conquest of Algeria, his speeches on foreign policy before the Assembly, are all evidence of an imperialistic, colonialist and racist individual. The man who had brought to light the ambiguity of social phenomena thus emerges as an ambivalent and incoherent figure: the political philosopher vs. the National Assembly deputy, the defender of human dignity vs. the individual reluctant to recognise the social and political rights of a large part of the human race, the moralist in the Americas vs. the imperialist coloniser in Algeria and overseas territories.

KEY WORDS: Tocqueville; slavery; colonialism; Algeria; racism.

CÓMO CITAR ESTE ARTÍCULO/CITATION: Usategui Basozabal, Elisa, «Alexis de Tocqueville, del Humanismo cívico al nacionalismo excluyente», Hispania, 81/267 (Madrid, 2021): 129-158. https://doi.org/10.3989/hispania.2021.005.

\section{INTRODUCCIÓN}

El objetivo de la obra de Alexis de Tocqueville es conocer las tendencias del proceso democrático en marcha para instruirlo y orientarlo, de cara a la construcción de una sociedad que permita el pleno desenvolvimiento y desarrollo material y moral del ser humano. Tocqueville, que ha rechazado todo movimiento lineal de la historia, es consciente de que las sociedades modernas están sometidas a fuertes tensiones y ambivalencias ${ }^{2}$, y que para articular los valores igualitarios y la libertad política tiene que sacar a la luz todas las formas posibles de poder que pueden acabar con la libertad. Su originalidad estriba en que detecta esos peligros en las dos dimensiones que, en su opinión, estructuran la democracia: la soberanía del pueblo, principio rector de la democracia en cuanto régimen político, que puede desembocar en la tiranía de la mayoría, y el

\footnotetext{
${ }^{2}$ MANENT, 2007: 73.
} 
individualismo, proceso caracterizador de la democracia como estado social, que conlleva el riesgo de caer en la tiranía de la opinión pública y en las garras de un poder totalizante y totalitario, al que nuestro autor denomina «nuevo despotismo».

De ahí que, por una parte, para minimizar el peligro de la tiranía de la mayoría, Tocqueville apele a la justicia adoptada por la mayoría de todos los hombres, que confronta a la mayoría concreta de un determinado país, y que confiere a los individuos el derecho de resistencia a todas aquellas decisiones políticas enfrentadas a la justicia en nombre de la soberanía del género humano ${ }^{3}$. Y que, por otra parte, para impedir el advenimiento de un poder cuasi absoluto, construya y extienda en el espacio social y político una pluralidad de poderes y sus correspondientes contrapoderes; de esta manera se impedirá su tendencia natural al acrecentamiento y, por el contrario, se favorecerá su (también) tendencia natural a la libertad. Son los propios ciudadanos democráticos quienes tienen que alzarse por encima de ellos, salir del círculo de sus intereses privados, asumir su responsabilidad individual, política y social frente a la masa, escuchar y dejarse llevar por su deseo innato de libertad y hacer surgir de la igualdad, y, nunca contra ella, sino a su través, la libertad ${ }^{4}$. Es decir, se trata de poner en marcha estrategias que mantengan despiertos a los ciudadanos, les inciten a la resistencia y desarrollen en ellos la pasión por la libertad.

De cara a dichos objetivos, Tocqueville se propone inflamar en la democracia muchos de los valores aristocráticos, como son, entre otros, el gusto por la excelencia, el respeto a la propia individualidad, el sentido de la independencia personal y la defensa de los derechos individuales. Sin embargo, la libertad como independencia individual solamente es justa si va unida a un derecho igual para todos a dicha independencia, derecho que debe estar sancionado y protegido legalmente. La justicia confiere el contenido moral a la libertad y viene dada por la idea de derecho igual para todos. Pero, por otra parte, solamente si se introduce la virtud cívica de los antiguos en la noción moderna de los derechos se conseguirá combatir el individualismo en las sociedades democráticas. Su resultado es la libertad cívica tocquevilliana, esto es, una libertad política compuesta básicamente de dos dimensiones: el derecho a participar en el gobierno, pero también el deber de actuar políticamente.

La libertad cívica tocquevilliana nos remite a ciudadanos capaces de salir del ensimismamiento al que el individualismo democrático les ha conducido, conscientes de que la libertad y la igualdad a la que aspiran no es posible si no luchan al mismo tiempo para que el conjunto de ciudadanos goce de

\footnotetext{
3 TOCQUEVILLE, 1989: 245-246.

${ }^{4}$ ROVIELLO, 2008.
} 
una libertad semejante a la suya. Ciudadanos independientes que se saben no autosuficientes y ven necesaria la colaboración entre todos los miembros de la comunidad ${ }^{5}$.

Por todo ello, no cabe una interpretación estrictamente neoliberal del pensamiento de Tocqueville 6 . De alguna manera, su noción de libertad no puede ser interpretada únicamente como la independencia del individuo frente al sistema político y al Estado, sino la independencia del individuo dentro del sistema político, gracias a una participación activa en dicho sistema. Tocqueville quiere mostrar que la independencia del individuo y su refugio en la esfera privada, proclamada con tanto ardor por el liberalismo, tiene como efecto paradójico el aumento de la acción del Estado.

Tampoco hay que leer a Tocqueville desde el comunitarismo, pues no se trata de dar marcha atrás en la historia, no se trata de recuperar viejos valores, se trata de hacer camino al andar y no mirar hacia atrás, de construir un «nosotros» que permita pensar en uno mismo y a la vez vivir para los demás. Desde esas claves cobran su auténtico sentido y significado sus propuestas: la doctrina del interés bien entendido, la descentralización administrativa, la libertad de prensa, el asociacionismo ciudadano o su defensa de la religión.

Sin embargo, hay una cuestión donde su noción de libertad cívica y su defensa de la justicia, su respeto al otro, su afán de alumbrar un «nosotros», en una palabra, su ímpetu ético, quedan significativamente ensombrecidos: su concepción de la política exterior francesa y la cuestión colonial, más concretamente, su manera de afrontar la eliminación de la esclavitud en las colonias francesas de ultramar y de encarar la conquista de Argelia. Son páginas que en muchas ocasiones nos muestran un Tocqueville reaccionario, imperialista y con planteamientos claramente colonialistas y nacionalistas ${ }^{7}$. Esta contradicción teórica y vital cobra toda su fuerza si se contrapone el humanismo que desprenden las páginas dedicadas en La Democracia en América y en los Cuadernos de viaje a la suerte de los indios y negros en América con los informes y los artículos de nuestro autor sobre la situación de Argelia y sobre la emancipación de los esclavos en las colonias francesas de las Antillas. Su sensibilidad, humanidad y sentido ético de la vida humana parecen ocultarse cuando se refiere a la heterogénea población que cubre el territorio de Argelia y cuando planifica el proceso de liberación de los esclavos en las Antillas francesas.

\footnotetext{
5 ROS, 2001: 190-193.

${ }^{6}$ BOESCHE, 1987. KAHAN, 1992. ANTOINE, 2003. COUTANT, 2007.

7 LUSTE BOULBINA, 2008a: 109.
} 


\section{TOCQUEVILLE, EL FILÓSOFO MORAL}

\section{El exterminio de los indios}

Coincidimos con Benoît y Jardin ${ }^{8}$ en que la imagen tocquevilliana del indio americano se va modificando en el transcurso de su estancia en EE.UU. En los comienzos de la aventura americana, le imaginaba como un ser libre, fuerte y recio, obligado a sobrevivir en medio de una naturaleza salvaje. Sin embargo, un episodio en Búfalo le despertaría de estas fantasías, al toparse con unos cuerpos lacerados por los estragos de una civilización extraña ${ }^{9}$ y abandonados a su suerte por el hombre blanco, hipócrita y racista:

¿Qué valor tiene la vida de un indio?». Ese era, en el fondo, el sentir general. En el corazón de esta sociedad tan civilizada, tan mojigata, tan pedante de moralidad y de virtud, se ocultaba una insensibilidad total, una suerte de egoísmo frío e implacable en todo lo referente a los indígenas de Norteamérica ${ }^{10}$.

A medida que Tocqueville se adentra en los territorios más alejados del hombre blanco, convive con los indios y conoce las costumbres y la cultura de las diferentes tribus, crece su admiración y respeto por el pueblo indio. Comprueba, por sí mismo, que, cuando se alejan de la influencia perniciosa de los blancos y están en su medio ambiente natural, son honestos, hospitalarios, serviciales, fieles, sinceros y cariñosos.

Los indios presentan rasgos y valores aristocráticos: la repulsa al trabajo, el amor a la libertad, el orgullo y la dignidad, la entereza ante el sufrimiento. Estos valores no les impiden ser feroces en la guerra e, incluso, inhumanos. Sin embargo, en tiempos de paz solamente son temibles cuando beben ${ }^{11}$.

Pero los indios están condenados a desaparecer. Pertenecen a una cultura nómada y cazadora ${ }^{12}$, impermeable a la industria y a la técnica, a la civilización y al progreso. Jamás se plegarán a los moldes culturales del hombre blanco, no por incapacidad o por su menor valía ${ }^{13}$, sino porque desprecian su manera de vivir y, en el fondo, se ven orgullosamente superiores. Frente al amor y al bienestar material del hombre blanco, el indio ha encontrado en la libertad, la independencia y la vida natural el origen de su dignidad y la razón de su ser. Confían ilusamente que podrán resguardarse un día en algún territorio inexpugnable para el hombre blanco. Inútil esperanza, la raza blanca llegará hasta los

\footnotetext{
${ }^{8}$ BENOÏT, 2005. JARDIN, 1984.

9 TOCQUEVILLE, 1957: 343-344.

10 TOCQUEVILLE, 1957: 345.

11 TOCQUEVILLE, 1998: 132.

12 TOCQUEVILLE, 1998: 158.

13 TOCQUEVILLE, 1957: 221-222.
} 
confines del territorio americano y en pocos años talará los bosques, diezmará los animales salvajes y el indio no tendrá donde refugiarse ni sabrá dónde buscar su alimento ${ }^{14}$. El hombre blanco sabe que el indio y su mundo están heridos de muerte y espera pacientemente su final. Tocqueville en «Quince días en el desierto» hace un elogio muy rousseauniano del estilo de vida del indio americano ${ }^{15}$.

Entre el indio y el blanco, el mestizo. Su vida es una eterna duda entre dos orígenes antagónicos y, quizás, muchas veces la muerte les sorprenda sin resolver el sentido de su existencia ${ }^{16}$. Sin embargo, en algunas de sus notas de viaje, Tocqueville otorga al mestizo un papel fundamental de mediador entre el hombre blanco y el indio, el puente necesario para la posible integración del indio en el mundo del hombre blanco ${ }^{17}$.

Desde que pisa tierras americanas, Tocqueville percibe y critica la hipocresía que envuelve el genocidio de los americanos con el pueblo indio. El gobierno, los habitantes de las grandes ciudades, los colonos, los recién venidos, es decir, la ciudadanía entera, están convencidos de que Dios mismo aprueba la degradación y aniquilación consciente, sistemática, silenciosa y legal de los indios por unos hombres que se ven a sí mismos puros, religiosos y humanos frente a la animalidad que proyectan en aquellos de los que son sus depredadores ${ }^{18}$. Tocqueville se asombra de la poca piedad e inmensa doblez del hombre civilizado ante la desaparición de un gran pueblo, que solamente ha tenido la mala suerte de entrar en contacto con una civilización más avanzada y más egoísta.

Los americanos, hombres reputados por su filantropía, gente razonadora y sin prejuicios, buenos ciudadanos, abiertos al progreso y amantes de la libertad y la democracia, se imaginan, al igual que los españoles, que Dios les ha dado la plena propiedad del Nuevo Mundo y de sus habitantes. Sin embargo, según nuestro autor, mientras en la América española se produce finalmente un mestizaje entre conquistados y conquistadores, en los Estados Unidos los hombres blancos llevan adelante una aniquilación fría, calculada y civilizada de la población india. Es decir, lo que en nuestros tiempos llamaríamos una eficaz política de limpieza étnica ${ }^{19}$.

Cuanto más conoce Tocqueville la dura realidad de los indios, más le duele y le apena la manera en la que esos desdichados son tratados por sus hermanos civilizados de Europa. Engañados por los comerciantes, despojados por los colonos, desterrados por el gobierno, humillados y despreciados por todos, no

\footnotetext{
14 TOCQUEVILLE, 1961: 342.

15 TOCQUEVILLE, 1957: 379.

16 TOCQUEVILLE, 1957: 380.

17 TOCQUEVILLE, 1957: 149, 204.

18 TOCQUEVILLE, 1957: 345.

19 TOCQUEVILLE, 1998: 159-160.
}

Hispania, 2021, vol. LXXXI, n. ${ }^{\circ}$ 267, enero-abril, págs. 129-158, ISSN: 0018-2141, e-ISSN: 1988-8368 https://doi.org/10.3989/hispania.2021.005 
hay nada en todo lo que Tocqueville observa que haga justicia a los llamados salvajes, mil veces más inofensivos y honrados que el hombre blanco. Y todo «con una facilidad maravillosa, tranquilamente, legalmente, filantrópicamente, sin sangre, sin violar ningún principio moral a los ojos del mundo. No se podría mejor destruir a los hombres respetando las leyes de la humanidad $\rangle^{20}$.

\section{LA SUERTE DE LOS NEGROS}

Tocqueville analiza la situación de los negros como el ejemplo más palmario del racismo y de la intolerancia étnica del hombre blanco angloamericano. Éste, a diferencia de los españoles y los franceses, que, por ejemplo, en Nueva Orleáns, han generado una importante población mulata, apenas se mezcla con la raza negra. Por el contrario, ha elaborado toda una legislación y mantenido unas costumbres que separan drásticamente ambas razas.

En los inicios de su viaje por el territorio americano, Tocqueville estaba convencido de que estas actitudes intolerantes hacia los negros eran propias de individuos de bajo nivel cultural y social. A medida que amplía sus relaciones sociales y conoce personas de todos los estratos sociales, se topa con gentes pertenecientes a la élite intelectual y económica del país apoyando la esclavitud y el status quo de los negros, sosteniendo expresamente y sin vacilación alguna su pertenencia a una especie inferior.

Ahora bien, mientras Tocqueville hace responsable de la aniquilación de los indios a la ciudadanía blanca en general, con respecto a la población negra, en sus notas de viaje aparecen testimonios de hombres blancos abolicionistas, no segregacionistas, defensores de la igualdad intelectual de ambas razas y de la mejora del bienestar de los negros en igualdad con los blancos. Es decir, en EE. UU. encontramos una mayor sensibilidad hacia la esclavitud y sus implicaciones económicas y sociales que hacia la suerte de los indios.

La esclavitud configura la fisionomía de los pueblos y el carácter de sus moradores. Los estados de Ohio y de Kentucky le permiten comprobar de una manera directa los efectos de la esclavitud y de la libertad en el estado social de un pueblo. Ambos estados están separados únicamente por un río, el suelo es igualmente fértil en ambos lados, su posición es también la misma, sin embargo, todo es diferente. El lado del río donde la esclavitud ha sido abolida presenta una floreciente actividad comercial e industrial, en la otra orilla su población vegeta y languidece. El esclavismo genera un sistema social que deshonra y desprecia el trabajo, el esfuerzo, la creatividad, la ciencia y el espíritu emprendedor, generando la ociosidad, la ignorancia, el orgullo, la pobreza y la 
sinrazón. Resulta un lastre económico y un empobrecimiento de la dignidad humana. Como dirá en La Democracia en América, es un pecado contra el espíritu y un crimen contra la humanidad ${ }^{21}$. Los efectos de la esclavitud evidencian que el hombre no está hecho para la esclavitud y que «cette vérité est encore mieux établie peut-être par le maître que par l'esclave»»"2.

En Kentucky y en Tennessee tiene la posibilidad de penetrar en la psicología de los pioneros blancos esclavistas, procedentes generalmente de Virginia. Son hombres que arrastran una vida miserable, en unas condiciones materiales ínfimas, en casas mal construidas. Sin embargo, presentan un orgullo anacrónico de superioridad racial y de rechazo al trabajo manual, mantienen unos pocos esclavos que cultivan malamente sus tierras y realizan aquellas labores que sus amos consideran deshonrosas, mientras ellos pasan el tiempo fumando, charlando y cazando. Lectores de periódicos y con el espíritu filosófico y argumentativo de sus parientes ingleses, hospitalarios y cordiales con los visitantes de su mismo color de piel, en su miseria presentan rasgos semejantes a los pequeños hidalgos de la vieja Europa ${ }^{23}$.

Tocqueville, cerca de Montgomery, en el estado de Alabama, observa, en las proximidades de la mansión principal de una plantación, a la hija del dueño jugando con sus dos criadas. A través de esta sencilla escena cotidiana y con unas pequeñas pinceladas, nuestro autor es capaz de transmitirnos las reglas que rigen las relaciones entre las tres razas que pueblan el territorio americano y sus personalidades respectivas: la altanería y superioridad de la niña blanca, la sumisión de la criada negra y el sentido de libertad y de independencia de la criada india ${ }^{24}$.

Más tarde, en la primera Democracia, recordando ésta y otras escenas semejantes, subrayará la degradación moral que la esclavitud ha supuesto para el hombre negro. El hábito de la servidumbre le ha dado pensamientos y ambición de esclavo, admirando a sus tiranos, más aún de lo que los odia, y poniendo su alegría y orgullo en la servil imitación de sus opresores amos ${ }^{25}$. De alguna manera, la propia situación de servidumbre dificulta la emancipación. Y se comprende la dificultad para que surja en los negros el deseo de romper sus cadenas, si al envilecimiento espiritual que supone la esclavitud, sumamos el embrutecimiento intelectual al que sus amos les someten, no permitiéndoles el acceso a la mínima instrucción, ni tan siquiera a leer y escribir.

La esclavitud está totalmente incrustada en el alma y en las costumbres de la ciudadanía de las dos razas, hasta tal punto que, aunque se cambiaran las

\footnotetext{
${ }^{21}$ TOCQUEVILLE, 1961: 30.

22 TOCQUEVILLE, 1961: 284.

23 TOCQUEVILLE, 1961: 287.

24 TOCQUEVILLE, 1957: 196.

25 TOCQUEVILLE, 1961: 332-333.
}

Hispania, 2021, vol. LXXXI, n. ${ }^{\circ}$ 267, enero-abril, págs. 129-158, ISSN: 0018-2141, e-ISSN: 1988-8368 https://doi.org/10.3989/hispania.2021.005 
leyes y se otorgara a los negros los mismos derechos que a los blancos, los propios hábitos sociales fuertemente impregnados de racismo imposibilitarían su ejercicio $^{26}$. En América, eliminar las desigualdades legales entre blancos y negros no es suficiente para que se instaure una verdadera igualdad. El recuerdo de la esclavitud deshonra a la raza y la raza perpetúa el recuerdo de la esclavitud..$^{27}$ De tal modo, la eliminación de la esclavitud solo resuelve una parte del problema y no asegura un mejoramiento en las condiciones materiales de los negros $^{28}$. Cuando Tocqueville analiza las tendencias tiránicas de la mayoría blanca y sus prejuicios raciales, aporta un elemento nuevo para la época y sumamente actual en los análisis teóricos sobre la construcción de las identidades en la posmodernidad: presenta a la raza como una identidad construida socialmente, definida casi totalmente por la opinión de la mayoría ${ }^{29}$.

Todos estos hechos le llevan a la convicción de que las dos razas no se mezclarán jamás en los Estados Unidos: se aborrecen y viven su coexistencia como una condenación. Tocqueville cree que la guerra entre ellas será inevitable y la paz solamente sobrevendrá cuando una de las dos haya desaparecido de la faz de la tierra ${ }^{30}$. De ahí que considere la presencia de los negros como uno de los peligros que amenaza el futuro de los Estados Unidos ${ }^{31}$.

Por otra parte, en su viaje a Nueva Orleáns, Tocqueville se va a interesar por la suerte de los mulatos. En los cuadernos y en las notas de viaje no concede al mulato ninguna capacidad de mediación, como lo hizo con el mestizo. El mulato, despreciado por los negros y los blancos, odia más al negro que los propios blancos. Tocqueville le compara con los lacayos de los grandes señores que, negando su clase social, llaman chusma al pueblo ${ }^{32}$. Sin embargo, diversas personalidades entrevistadas le señalan que la élite cultural de los mulatos, humillados por el rechazo y el desprecio de los blancos, puede encabezar un día la lucha de los negros por su emancipación: aportan rabia, odio e inteligencia.

\section{El DiPUTAdo TOCQUEVILLE}

Hay que tener a la vista, a la hora de analizar los planteamientos políticos del diputado Tocqueville, que su noción de nación está íntimamente unida con el Estado. Parte de una concepción liberal del Estado-nación, en la que aquel

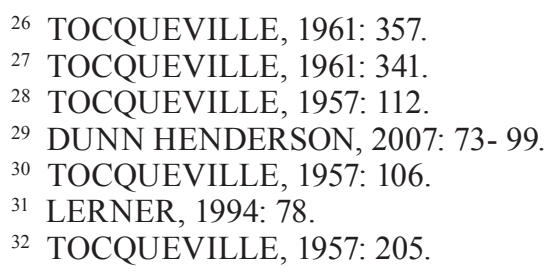


aparece como la cristalización jurídico-política de la nación preexistente. Es decir, la nación es la comunidad base sobre la que se superpone el Estado como organización. De ahí que, en ocasiones, a lo largo de su obra haya una identificación de la comunidad nacional con la organización política. «La Francia» es la comunidad nacional organizada en Estado: ambos conceptos están intrínsecamente unidos en su concepción de Francia.

Ahora bien, como en buena parte del pensamiento liberal, en su idea de nación late la tensión entre dos principios: el principio estatal, que conduce a la razón de Estado, es decir, una acción dirigida al engrandecimiento de Francia por encima de toda referencia humanista; y el principio democrático, que exige mayores cotas de participación, libertad y control por parte de los ciudadanos. De alguna manera, el principio democrático nos llevaría al Tocqueville del republicanismo cívico y el principio estatal reflejaría al diputado Tocqueville - en un periodo de su actividad política, ministro de Asuntos Exteriores-, preocupado exclusivamente por los intereses y la grandeza material de Francia.

\section{La emancipación de los esclavos}

Tocqueville expone su posición sobre la esclavitud y su abolición en el periódico Le Siècle, en seis capítulos que publica durante los meses de noviembre y diciembre de $1843^{33}$. La última intervención parlamentaria en torno a la cuestión de la abolición de la esclavitud tiene lugar el 30 de mayo de 1845 con ocasión de la discusión de la Ley sobre el régimen de los esclavos en las colonias ${ }^{34}$.

Indudablemente, los problemas de convivencia entre las distintas razas observados en los Estados Unidos son un factor explicativo importante de su interés por la suerte de los negros en las colonias francesas de ultramar. En sus intervenciones en la Cámara, en sus escritos, en su correspondencia, se suceden las condenas a la esclavitud en nombre del derecho natural y del principio de igualdad subsiguiente. En este aspecto, se reclama y se muestra heredero de los principios humanistas de la Ilustración: «El hombre no tiene el derecho de poseer al hombre y el hecho de la posesión siempre ha sido y es todavía ilegítimo». Abundan descalificaciones de la esclavitud como una institución inicua y odiosa, contraria a todos los derechos naturales de la humanidad.

Tocqueville, desde una defensa férrea del postulado de la igualdad de los seres humanos, considera las tesis racistas justificaciones inventadas por los esclavistas para justificarse. Determinadas razas por diferentes circunstancias sociológicas e históricas han alcanzado niveles inferiores de civilización, pero todas tienen la misma capacidad natural para alcanzar idénticos niveles

\footnotetext{
33 TOCQUEVILLE, 2008: 83-130.

34 TOCQUEVILLE, 2008: 131-153.
}

Hispania, 2021, vol. LXXXI, n. ${ }^{\circ}$ 267, enero-abril, págs. 129-158, ISSN: 0018-2141, e-ISSN: 1988-8368 https://doi.org/10.3989/hispania.2021.005 
de civilización. En este sentido hay que entender su expresión «le nègre est civilisable».

Apoya su postura en los principios cristianos. El cristianismo es una religión de hombres libres e iguales. Sin embargo, los cristianos, con el paso del tiempo, perdieron de vista sus principios éticos y se contentaron con defender la igualdad del género humano ante los ojos de Dios. Pero en la tierra la mayoría de ellos acabaron apoyando la esclavitud con sus silencios o con sus prácticas o con sus palabras. Hubo que esperar a la Revolución francesa para que, al volver los hombres su mirada a las cosas terrenales, surgieran los movimientos abolicionistas. Este es el planteamiento moral de la esclavitud en nuestro autor.

Sin embargo, la esclavitud no es solamente un problema ético, es también una institución social, con fuertes implicaciones económicas y sociales. Y cuando habla el diputado Tocqueville aparece el hombre de Estado y desaparece el filósofo moral. Indudablemente lo ideal sería una coincidencia de los principios éticos, políticos y los intereses particulares. Pero nuestro hombre político no lo cree posible: como dice, Todorov, ahora es «la política quien evalúa la moral y no a la inversa» ${ }^{35}$. Es la moral quien está sometida a la política: «La humanidad y la moral han reclamado a menudo, y muchas veces de forma imprudente, la abolición de la esclavitud. Hoy en día, es la necesidad política quien la impone $)^{36}$.

Nuestro autor deja a un lado sus reflexiones éticas ante el espectáculo que le ofrecían en los Estados Unidos las dos orillas del rio Ohio y asume una posición pragmática e instrumental ante la abolición de la esclavitud en tierras coloniales francesas. De hecho, sus escritos y sus intervenciones en la Asamblea Nacional son un buen ejemplo de lo que se ha denominado su «ambidiestrismo» ${ }^{37}$ : deseo de conciliar lo inconciliable, los principios éticos con el más puro utilitarismo económico, los intereses de los esclavos y los de los propietarios de las plantaciones, la libertad de los negros y la propiedad de los blancos, la dignidad de los esclavos y los intereses de la patria ${ }^{38}$. Desaparece el filósofo social, que mira desinteresada y éticamente una realidad que no le compromete, y aparece el político, que contempla las colonias americanas con la obligación de atender prioritariamente a los intereses de la nación. «No

35 TODOROV, 1988b: 13.

36 TOCQUEVILLE, 2008: 33.

37 GUINERET, 2007: 101.

38 «J'ai toujours été fort opposé au parti abolitionniste, en tant que ce parti voulait amener une abolition prématurée et dangereuse de l'esclavage dans le pays où cette abominable institution a toujours existé. Mais l'introduire dans de nouveaux États, répandre cette peste horrible sur une grande surface de la terre qui en a été jusqu'ici préservée, imposer tous les crimes et toutes les misères qui accompagnent l'esclavage à des millions d'hommes a venir (maîtres ou esclaves) qui pouvaient y échapper, est un crime contre le genre humain, et cela me paraît affreux et sans excuse». (TOCQUEVILLE, 2002: 1248). 
se trata en absoluto de saber si la esclavitud es malvada, si debe acabar señala Tocqueville, en ese sentido-, sino de cuando y como conviene que acabe $»^{39}$.

El diputado Tocqueville no tiene en mente, como objetivo primero, la abolición de la esclavitud, sino el mantenimiento de las colonias. Así, ante la importancia comercial y estratégica para Francia de los territorios de ultramar, la abolición de la esclavitud tiene un carácter fuertemente instrumental ${ }^{40}$.

Por otra parte, tiene como referencia el proceso de la abolición de la esclavitud en las colonias inglesas del Caribe. La emancipación de los esclavos se había producido en 1833, pero tenía un periodo transitorio preparatorio hasta alcanzar la total independencia. Durante ese tiempo, los negros seguían trabajando gratuitamente para sus antiguos propietarios durante un cierto número de horas por semana. Los colonos recibían una compensación económica por los trastornos que estos cambios introducían en la organización del trabajo de sus plantaciones. Debido a la presión de la opinión pública y las reiteradas campañas de los abolicionistas, el gobierno inglés eliminó este «aprendizaje en la libertad» y dictó la emancipación total. La existencia en las colonias de grandes extensiones de tierras muy fértiles a precios muy asequibles, permitió a los trabajadores negros liberados emigrar en masa a esas tierras, donde establecieron pequeñas granjas para su subsistencia, originando una falta de mano de obra en las grandes plantaciones ${ }^{41}$. "Por consiguiente, el gobierno inglés habría debido negar a los negros, al menos por algún tiempo, el derecho de adquirir tierras (...). Al salir de la esclavitud, esta restricción de la libertad habría sido aceptada sin protestas por la población negra» ${ }^{42}$.

Sin embargo, en las cartas en Le Siècle, Tocqueville reconoce elementos muy positivos en el proceso emancipatorio inglés. En primer lugar, no se ha producido un aumento de la criminalidad, ninguna insurrección, «no ha costado la vida de un solo hombre, y, sin embargo, en las colonias inglesas, los negros son doce veces más numerosos que los blancos» ${ }^{43}$. Además, «en cuanto los negros han sentido el aguijón de la libertad, se han precipitado, por así decirlo hacia las escuelas» ${ }^{44}$. También han aumentado los matrimonios, y los negros, una vez liberados, han manifestado los mismos gustos, el mismo deseo de bienestar, la misma aspiración de mejorar sus condiciones materiales, y las mismas necesidades de los pueblos civilizados ${ }^{45}$.

\footnotetext{
39 TOCQUEVILLE, 2008: 30.

40 TOCQUEVILLE, 2009: 13.

${ }^{41}$ GREEN, 1976.

42 TOCQUEVILLE, 2009: 25.

43 TOCQUEVILLE, 2009: 19.

44 TOCQUEVILLE, 2009: 19.

45 TOCQUEVILLE, 2009: 19-20.
}

Hispania, 2021, vol. LXXXI, n. ${ }^{\circ}$ 267, enero-abril, págs. 129-158, ISSN: 0018-2141, e-ISSN: 1988-8368 https://doi.org/10.3989/hispania.2021.005 
Reconoce, sin embargo, que el éxodo de la mano obrera, el incremento de los salarios y la disminución de la producción azucarera han provocado en los colonos grandes dificultades económicas y han arrastrado a la ruina a buen número de ellos. Precisamente esto es lo que se ha de evitar, pues «si los negros tienen derecho a la libertad, es incuestionable que los colonos tienen el derecho de no arruinarse a causa de la libertad de los negros»».

En coherencia, Tocqueville propone la libertad inmediata y simultánea de todos los esclavos de las colonias, pero con una serie de condiciones:

1-. Un periodo preparatorio de 10 años hasta la emancipación total. Los negros seguirán obligados a trabajar gratuitamente, aunque obtendrán determinados derechos, como contraer matrimonio, adquirir bienes o comprar su libertad. Se crearán escuelas para ellos y se les dará educación religiosa e instrucción. Al final del periodo, el trabajo se hará productivo y la esclavitud desaparecerá en los hechos y en las palabras ${ }^{46}$.

2-. Los negros, una vez liberados, no disfrutarán de los mismos derechos que los trabajadores de la metrópoli. En los primeros años, los negros liberados gozarán de una libertad limitada. Los antiguos esclavos estarán obligados a residir en la colonia. Elegirán libremente su profesión, pero no podrán estar ociosos ni trabajar por cuenta propia. El gobierno de la colonia fijará anualmente el máximo y el mínimo de los salarios ${ }^{47}$.

3-. Los negros liberados tendrán temporalmente prohibido adquirir tierras. Tocqueville no cree que esta medida sea injusta, arbitraria y abusiva, sino que les iguala a la población obrera de la metrópoli, donde el alto precio de las tierras ha impedido a los obreros y jornaleros comprarlas y hacerse propietarios. De hecho, para nuestro autor «no hay en ello el menor atisbo de tiranía; el hombre que solo encuentre este obstáculo a la salida de la esclavitud no parece tener derecho a quejarse $\rangle^{48}$. Exige, pues, a los negros seguir manteniendo una actitud servil: sin derecho a protestar de las limitaciones impuestas y agradecidos porque los amos les devuelven derechos que contra toda ética les han arrebatado durante generaciones.

Finalmente, Tocqueville intentará atraer a los colonos a la causa abolicionista. Les muestra el sinsentido de la esclavitud en el contexto internacional de la época y los peligros que genera para el desarrollo económico de las colonias $\mathrm{y}$, por tanto, para su propio beneficio ${ }^{49}$. Además, les propone un conjunto de garantías y medidas proteccionistas:

\footnotetext{
46 TOCQUEVILLE, 2009: 28-29.

47 TOCQUEVILLE, 2009: 29.

48 TOCQUEVILLE, 2009: 31.

49 TOCQUEVILLE, 2009: 6.
} 
1-. Establecer un plazo que permita a los colonos prepararse para hacer frente a los gastos que les va a ocasionar contratar trabajadores libres en la producción de azúcar ${ }^{50}$.

2-. El Estado compensará a los colonos la inevitable disminución de la producción de azúcar y la bajada de su precio ${ }^{51}$.

3-. Se concederá «a los colonos una indemnización que represente el valor venal de los esclavos liberados $»\rangle^{52}$.

A pesar de la claridad de su lenguaje, llama la atención que no haya entre los estudiosos de la obra de nuestro autor una unanimidad sobre su posición en el tema de la esclavitud. Benoît puede considerarse el representante de la exégesis más favorable. Atribuye un carácter profundamente moral al combate tocquevilliano a favor de la abolición. Interpreta la evidente primacía de la dimensión económica sobre los criterios de índole moral como una simple estrategia argumentativa, una pura táctica parlamentaria para conseguir en la Asamblea el voto de los diputados, más interesados en el progreso económico de las colonias que en la suerte de los esclavos. El mismo argumento le sirve para explicar su apoyo a la concesión de ayudas a los colonos y a la limitación de derechos y libertades a los negros emancipados ${ }^{53}$.

En cambio, sus críticos más duros, entre los que cabe señalar a Seloua Luste Boulbina, Tzvetan Todorov y Marc Viellard, consideran a nuestro autor un auténtico racista. Indudablemente, denuncia la esclavitud y defiende la igualdad ante la ley, pero jamás acompaña esta defensa con un apoyo decidido a la igualdad social ${ }^{54}$. En opinión de Seloua Luste Boulbina, sus análisis de la esclavitud parten de una visión negativa de los negros: son descritos siempre de forma peyorativa y despectiva. Desde una posición eurocéntrica y blanca, elimina el protagonismo de los esclavos en su lucha por la libertad: la abolición de la esclavitud es el resultado de la decisión ilustrada y clarividente de los amos, y no el resultado del esfuerzo doliente de los esclavos. Los negros son vistos como sujetos mudos y pasivos, son beneficiarios y no actores de su emancipación ${ }^{55}$. En su recalcitrante chovinismo, convierte en protagonistas de la historia de la liberación de los esclavos a los franceses, quienes, portando el estandarte de la igualdad y la libertad por el mundo, han posibilitado el inicio de los procesos abolicionistas ${ }^{56}$.

\footnotetext{
50 TOCQUEVILLE, 2009: 32.

51 TOCQUEVILLE, 2009: 33.

52 TOCQUEVILLE, 2009: 34.

53 BENOÎT, 2004: 102-103.

54 STOKES, 1990: 1-15.

${ }^{55}$ LUSTE BOULBINA, 2008b: 170.

${ }^{56}$ LUSTE BOULBINA, 2008b: 173.
}

Hispania, 2021, vol. LXXXI, n. ${ }^{\circ}$ 267, enero-abril, págs. 129-158, ISSN: 0018-2141, e-ISSN: 1988-8368 https://doi.org/10.3989/hispania.2021.005 
Por su parte ${ }_{2}$ Todorov interpreta el derecho a «no ser arruinado» como una defensa de la propiedad, de una propiedad basada en el expolio y en la expropiación de los derechos naturales básicos, como son la libertad y la igualdad de todos los hombres ${ }^{57}$. Tocqueville, «para evitar que la abolición de la esclavitud en las antiguas colonias francesas no tenga efectos nefastos (ruina de los propietarios, disminución del nivel industrial), liberando a los individuos, hay que mantener los territorios que habitan en estado de sumisión. En otros términos, el colonialismo tiene que remplazar a la esclavitud». ${ }^{58}$ Es decir, el abolicionista esconde en su interior un colonialista.

Ciertamente, en Tocqueville encontramos el deseo de lograr la cuadratura del círculo, es decir, aunar elementos humanistas y éticos con intereses manifiestamente colonialistas y euro-céntricos, como demuestra el siguiente texto:

Por muy digna de respeto que sea la situación de los negros y por muy sagrado que deba ser a nuestros ojos su infortunio, que es obra nuestra, sería injusto e improcedente preocuparse tan sólo de ellos. Francia no podría olvidar a aquellos de sus hijos que habitan en las colonias, ni perder de vista su grandeza, que exige que las colonias progresen ${ }^{59}$.

Ahora bien, también encontramos su convicción de la esencial inmoralidad de la esclavitud. El esclavo no es un ser moral en el sentido pleno del término, porque carece de aquello que otorga la moralidad al ser humano: la libertad. Solamente la libertad confiere responsabilidad al ser humano, sin la cual hablar de moralidad parece un contrasentido. Es en este sentido como hay que entender la intrínseca inmoralidad de la esclavitud, porque coloca al individuo en una a-moralidad completa, ya que destruye la humanidad en el ser humano y le coloca al nivel de los brutos. Con la libertad y los derechos que como ser humano le corresponden, el esclavo recobrará su humanidad arrebatada, el conjunto de los valores, el sentido del trabajo, el valor de la familia y de lo sagrado ${ }^{60}$.

Ciertamente, europeo, blanco, aristócrata, con un proyecto de carrera política en su mente, en su viaje por tierras americanas no vio la necesidad de acercarse a los negros e indagar en sus sentimientos, en su religión, en el interior de su mente y de su corazón, en una palabra, de acercarse a la realidad desde los ojos de un negro esclavo del sur o de un negro liberto del norte. Pero, también es cierto que nuestro autor rechazó siempre las tesis racistas y antisemitas de Gobineau por inmorales y peligrosas ${ }^{61}$, negadoras de la libertad, y ensalzado-

${ }^{57}$ LUSTE BOULBINA, 2008a: 115-116.

58 TODOROV, 1988b: 15.

59 TOCQUEVILLE, 2009: 32.

${ }^{60}$ TOCQUEVILLE, 2008: 34-45.

${ }^{61}$ Estamos en desacuerdo con TERRÉN, 2002: 11, al identificar los planteamientos tocquevillianos con las tesis racistas de Gobineau. 
ras de la fuerza y el cinismo, excluyentes de cualquier mirada ética del hombre, del mundo y de la política ${ }^{62}$.

\section{La mirada colonial: Argelia}

Para muchos de sus intérpretes, sus escritos sobre Argelia constituyen el «lado oscuro» ${ }^{63}$ de Tocqueville, por su falta de humanidad y carencia de principios éticos. Además, no son algo secundario en su pensamiento político, pues Argelia y su colonización ocupan un lugar de primer orden en sus preocupaciones y en su propia acción política ${ }^{64}$. De hecho, la obra tocquevilliana permite, en opinión de Mélonio, explorar una antinomia ideológica que se inicia en el XIX y que llega hasta nuestros días: «Un liberalismo democrático que programa la universalidad de los derechos individuales y la idea nacional que exalta el particularismo colectivo» ${ }^{65}$.

Tocqueville se nos presenta desde este ángulo como «un representante cualificado del universalismo democrático, que al mismo tiempo afronta el problema del nacionalismo en su doble forma histórica», es decir, defensor de la expansión colonial, pero, a su vez, consciente de que dicha política provocaría la emergencia del nacionalismo musulmán, basado en la guerra contra un enemigo común y en la exaltación de un particularismo religioso y cultural: la unidad árabe tomará cuerpo desde una hostilidad a Occidente ${ }^{66}$.

En este sentido, detectó las características que adoptaría el sentimiento y la identidad nacional en los pueblos oprimidos: por una parte, serán nacionalismos modernos y democráticos, porque asumirán la forma de Estado-Nación, pero, por otra parte, profundamente conservadores y tradicionalistas, en cuanto se presentarán como la salvaguarda de modos culturales tradicionales y restauradores de glorias pasadas. Es decir, nacionalismos que restituyen una Edad de Oro primigenia y recuperan una pretendida identidad originaria.

En todo caso, su interés por la acción de Francia en tierras argelinas se le despierta muy temprano. Así, aunque sus primeros escritos sobre Argelia datan de 1837, encontramos en fechas anteriores rastros de su interés por la colonización de esas tierras, en especial en su correspondencia con su primo Kergorlay ${ }^{67}$. Incluso en 1833 planea, con éste último, comprar y explotar una plantación

62 JARDIN, 1977: 200-219.

${ }^{63}$ SÁNCHEZ MEJÍA, 2009: XXVI.

${ }^{64}$ MÉLONIO, 2005: 337- 356; 1991: 5-24.

${ }^{65}$ MÉLONIO, 2005: 337.

${ }^{66}$ ROMAY BECCARIA. 2007: 305-319. DION, 1994: 219-227. MÉLONIO, 1991: 5-24.

67 JARDIN, 1962: 61-74. RICHTER, 25/3 (Cambridge, 1963): 362-398. BEGIN, XXX/2 (Toronto, 2009): 179:203.

Hispania, 2021, vol. LXXXI, n. ${ }^{\circ}$ 267, enero-abril, págs. 129-158, ISSN: 0018-2141, e-ISSN: 1988-8368 https://doi.org/10.3989/hispania.2021.005 
en África del Norte, concretamente en la zona del Sahel, y, también, anuncia su intención de aprender el árabe. El proyecto fracasa, pero le sirve para recabar información sobre el país, sus costumbres, sus habitantes y el proceso colonizador francés en marcha.

En 1837, en un momento de incertidumbre sobre el futuro de la colonia, Tocqueville tiene la intención de presentarse a la Asamblea por la circunscripción de Versalles; para darse a conocer y adquirir cierto prestigio como hombre de Estado, publica sobre la situación política de la colonia «Lettres sur l'Algérie» ${ }^{68}$, que aparecen los días 23 de mayo y 22 de agosto en La Presse de Seine-et-Oise.

Dos años después de haber sido elegido diputado, emprende con su amigo Beaumont su primer viaje a Argelia (mayo-junio de 1841), al que va provisto de las notas y las reflexiones que ha ido escribiendo de sus lecturas sobre la zona y sobre la acción de la administración francesa en esas tierras ${ }^{69}$. De vuelta a Francia, redacta un amplio Travail sur l'Algérie, síntesis de sus impresiones durante el viaje y de su visión general sobre la llamada «cuestión africana». De octubre a diciembre de 1846 efectúa un segundo viaje a la colonia y, en 1847, es ponente en la comisión encargada de informar el proyecto de ley que demandaba créditos extraordinarios para Argelia ${ }^{70}$. Su interés siempre se mantuvo vivo e intervino en varias ocasiones desde la tribuna de la Asamblea. De manera especial reclamaba una reorientación de la política colonial en Argelia y la creación de un ministerio especial. Así pues, entre 1837 y 1849, la colonia de Argelia se encuentra entre las grandes preocupaciones políticas de nuestro autor.

Tocqueville siempre se muestra partidario de la colonización de Argelia. En otras ocasiones, como en el caso de las colonias inglesas en la India, impregnaba su justificación del colonialismo de un tinte humanitario: el deseo y la obligación de las naciones europeas de llevar la civilización a tierras casi salvajes. Sin embargo, en el caso de Argelia, esta excusa no le servía, porque «hemos vuelto a la sociedad musulmana mucho más miserable, más desordenada, más ignorante y más bárbara que lo era antes de conocernos $\rangle^{71}$.

Entonces, ¿cómo legitima la presencia francesa en tierras argelinas? Por el interés nacional y la defensa del honor de Francia ${ }^{72}$. El abandono de las colonias representaría un signo claro de decadencia de la nación francesa y sería mucho más honorable para sus ciudadanos caer vencidos frente a las armas de otro país, que la huída y el abandono ${ }^{73}$. Al mismo tiempo, consideraciones estraté-

\footnotetext{
68 TOCQUEVILLE, 2009: 39-66; 2003, 43-60; 1988: 37-56.

69 TOCQUEVILLE, 1962; 2003: 60-96; 1991: 657-688, 761-796.

70 TOCQUEVILLE, 2003: 179-302.

71 TOCQUEVILLE, 1962: 323.

${ }^{72}$ LOSURDO (2007: 139) habla de un «patriotismo irritable» en Tocqueville.

73 TOCQUEVILLE, 2009: 67-68.
} 
gicas refuerzan su defensa de la conservación de Argelia: el Mediterráneo es una «mar político» y las costas del norte de África se sitúan frente a las costas de Francia ${ }^{74}$. Por lo demás, si Francia renuncia a Argelia, caerá en manos de otro pueblo europeo o bajo dominio musulmán, que, en cualquier caso, la utilizarían contra los intereses de la nación francesa.

Se entiende entonces la pregunta de Tocqueville en su Rapport sobre Argelia: «El dominio que ejercemos en la antigua Regencia de Argelia ¿es útil para Francia? $\gg{ }^{75}$. La respuesta es evidente: ante el interés nacional no cuenta para nada el provecho de la población autóctona, el sentido de la justicia, de la dignidad humana o la libertad de los pueblos y de los individuos. Incluso las repercusiones económicas de la colonización adquieren a sus ojos un tinte nacionalista: «El principal mérito de nuestras colonias no está en sus mercados, sino en la posición que ellas ocupan en el globo» ${ }^{76}$.

Este espíritu nacionalista explica muchas de las reacciones de Tocqueville en sus visitas a tierras argelinas y su manera de encarar la dominación y la colonización de esas tierras. Así, ante la violencia gratuita desplegada por las tropas francesas en la región, su rechazo viene del temor a que este tipo de conductas se vuelvan contra los intereses de Francia, provoquen la ruina de los colonos y la rebelión de las poblaciones autóctonas. En escasas ocasiones aparecen criterios morales y éticos: la suerte y los muertos «indígenas» le impor$\tan$ menos que su posible rebelión ${ }^{77}$.

Tocqueville es totalmente partidario de la dominación francesa de Argelia y para su logro - piensa - se requiere astucia y fuerza ${ }^{78}$. Astucia para enfrentar a las diversas tribus entre sí e impedir su unión bajo un mismo jefe. En cuanto a la fuerza, el liberal Tocqueville acaba aceptando para Argelia recurrir a toda violencia que no contradiga principios universales, cuyo contenido nunca concreta, y que pueden reducirse a evitar exterminios salvajes de la población civil. La violencia es inevitable, porque

La colonización sin dominación siempre será, a mi parecer, empresa incompleta y precaria (...). Comenzamos reconociendo que no teníamos enfrente a un

${ }^{74}$ «Lo cierto es que, si logramos mantener con firmeza y dominar de forma pacífica esta costa africana, nuestra influencia sobre los asuntos generales del mundo se vería muy acrecentada. Argelia posee dos enclaves que son, o pueden llegar a ser, fundamentales en el Mediterráneo [...] Estos dos enclaves [el puerto de Mazalquivir y Argel], que se apoyan uno a otro, situados frente a las costas de Francia, frente al mar político de nuestros días, incrementarían sin duda en gran medida la fuerza de Francia» (TOCQUEVILLE, 2009: 69).

75 TOCQUEVILLE, 1962: 311.

76 TOCQUEVILLE, 1962: 85.

77 TOCQUEVILLE, 1958: 216-217.

78 TOCQUEVILLE, 2009: 72- 80.

Hispania, 2021, vol. LXXXI, n. ${ }^{\circ}$ 267, enero-abril, págs. 129-158, ISSN: 0018-2141, e-ISSN: 1988-8368 https://doi.org/10.3989/hispania.2021.005 
verdadero ejército, sino a la propia población (...). No se trataba de vencer a un gobierno, sino de reducir a un pueblo ${ }^{79}$.

Ciertamente, ${ }_{2}$ Tocqueville no pierde su humanismo del todo y rechaza la guerra en favor del exterminio, por ser cruel y denotar falta de inteligencia. Sin embargo, para él la guerra colonial en Argelia no tiene nada que ver con la filantropía y los buenos sentimientos. Es una guerra despiadada, dirigida contra la población para su total dominación:

Si en Europa no se queman las cosechas, se debe a que por regla general la guerra se dirige contra los gobiernos y no contra la población (...). Pienso, por mi parte, que cualquier medio que sirva para hundir a las tribus debe ser empleado. Tan solo excepto aquellos que la humanidad y el derecho de las naciones reprueban ${ }^{80}$.

Y propone, en el Trabajo sobre Argelia, las siguientes medidas: la prohibición del comercio a los árabes, la devastación del territorio, la destrucción de todo lo que recuerde a una ciudad, la ocupación militar permanente, la construcción de hospitales para la tropa francesa, la creación de un ejército especial para África.

Sin embargo, la ocupación militar, aunque necesaria, no es suficiente: «Mientras no tengamos una población europea en Argelia, podrá decirse que estamos acantonados en las costas de África, pero no establecidos $\rangle^{81}$. Es necesario pues, colonizarla desde el principio, de tal modo que «en la medida de lo posible la colonización y la guerra vayan juntas». Colonizar es conseguir construir una sociedad en la que los colonos no se sientan extranjeros. De tal modo que «no nos tenemos que proponer en Argelia una colonia propiamente dicha, sino la extensión de la misma Francia al otro lado del Mediterráneo» ${ }^{82}$.

Por otra parte, la colonización dependerá de dotar de tierras fértiles a los colonos. Para ello, Tocqueville defiende, en su Trabajo sobre Argelia, diversas formas de adquisición: el «derecho de conquista», la «compra voluntaria»y, finalmente, la expropiación forzosa. Además, el nomadismo de las poblaciones autóctonas servía para cuestionar su derecho de propiedad sobre el territorio. Sin embargo, su posición se va suavizando desde su Trabajo sobre Argelia a sus Informes. El contexto social y político se ha modificado profundamente: la guerra está a punto de acabar, el líder árabe Abd-el-Ka-der se ha rendido tras fracasar su intento de pacto con Marruecos, se han establecido ya más de quince mil europeos en la colonia, de los cuales solo una pequeña parte son

\footnotetext{
79 TOCQUEVILLE, 2009: 152.

80 TOCQUEVILLE, 2009: 82-83.

81 TOCQUEVILLE, 2009: 96.

82 TOCQUEVILLE, 2009: 150.
} 
realmente colonos dedicados a trabajar la tierra, mientras que el resto vive agolpado en ciudades.

En cuanto a las relaciones entre los franceses y los árabes, comienza defendiendo una posible fusión en tierras argelinas de las diferentes razas ${ }^{83}$, pero termina respaldando la segregación total ${ }^{84}$. De ahí que proponga legislaciones separadas para los europeos y la población autóctona. No obstante, en sus Informes, considera importante que sean tratados con la mayor justicia posible para lograr disminuir su odio contra los colonos. Para ello, el respeto del derecho a la propiedad es un instrumento válido e importante. Por tanto, las tierras tan necesarias para la colonización se deben obtener a través de indemnizaciones «a quienes las poseen o disfrutan de ellas» ${ }^{85}$.

No podemos aspirar a suprimir los sentimientos hostiles que nuestro gobierno inspira, sino a mitigarlos; no podemos hacer que nuestro yugo sea amado, sino que parezca cada vez más tolerable; no podemos acabar con la repugnancia que en todo tiempo han manifestado los musulmanes hacia un poder extranjero y cristiano, sino hacerles descubrir que ese poder, pese a su reprobado origen, puede resultarles útil. Sería poco sensato pensar que llegaremos a unirnos a los indígenas por medio de una comunidad de ideas y costumbres, pero podemos aspirar a hacerlo por una comunidad de intereses ${ }^{86}$.

Sin embargo, en todo tiempo y en todo lugar, en la guerra y en la paz, se les ha de hacer ver su condición de vasallos. Jamás han de sentirse conciudadanos e iguales a los colonos franceses. Hay que evitar los excesos y la violencia gratuita para con ellos, pero las mejores tierras serán para los colonos franceses, las autoridades francesas no construirán gratuitamente mezquitas ni subvencionarán los viajes a la Meca, aunque se les ayudará a rehacer sus escuelas y no se les obligará a asistir a las europeas. En cuanto a la religión, podrán mantener sus creencias y se respetarán las escuelas coránicas, porque «hoy sabemos que fueron fanáticos mendicantes pertenecientes a sociedades secretas, una especie de clero irregular e ignorante, quienes inflamaron los ánimos de la población durante la última insurrección, y los que provocaron la guerra $\rangle^{87}$. De este modo, «no se trata por el momento de impulsarlos por la vía de la civilización europea — señala Tocqueville—, sino de hacerlo en el sentido de la suya propia» ${ }^{88}$. Esto no quita para que algunos árabes acaben europeizándose, por-

\footnotetext{
83 TOCQUEVILLE, 2009: 65.

${ }^{84}$ TOCQUEVILLE, 2009: 135.

85 TOCQUEVILLE, 2009: 162.

86 TOCQUEVILLE, 2009: 164.

87 TOCQUEVILLE, 2009: 161.

88 TOCQUEVILLE, 2009: 160.
}

Hispania, 2021, vol. LXXXI, n. ${ }^{\circ}$ 267, enero-abril, págs. 129-158, ISSN: 0018-2141, e-ISSN: 1988-8368 https://doi.org/10.3989/hispania.2021.005 
que - en palabras de nuestro autor- «el islamismo no resulta totalmente impenetrable para la luz del conocimiento ${ }^{89}$.

En cuanto al tipo de población a atraer a tierras argelinas, Tocqueville se muestra totalmente contrario al establecimiento de colonias militares y a las experiencias semisocialistas de los saintsimonianos. Tocqueville quería atraer a una población civil con deseos de mejorar sus condiciones materiales de vida. Para ello, había que procurarles unas condiciones de vida suficientemente atractivas como para inyectarles el deseo de emprender la aventura de la colonización: ventajas económicas y comerciales que les permitieran prosperar por sí mismos, una administración civil que les garantizase un mínimo de derechos y de libertades, un sistema legal alejado de todo tipo de arbitrariedad, un ejército que les mantuviera alejados y protegidos de los nativos. En una palabra, fundar una colonia francesa en Argelia exige dotarla de unas instituciones apropiadas a las condiciones de los franceses en dichas tierras.

Indudablemente, ${ }_{2}$ trasplantar la organización institucional metropolitana a un país en guerra, como es Argelia, plantea enormes problemas. Se trata de defender, por un lado, la libertad y garantizar, por otro, la seguridad. Misión casi imposible. Tocqueville propone diversas medidas: la creación de una administración civil, con un amplio margen de maniobra, a cuya cabeza se colocará siempre a un civil y nunca a un militar; la descentralización administrativa, aunque las normas más importantes deberán emanar de la administración central y el fomento de la libertad comunal, necesaria para enraizar a los pobladores a su nueva tierra, al fomentar los intereses colectivos y una actividad común. Sin embargo, expulsa de tierras argelinas las libertades que en la dos Democracias en América aparecen como básicas para edificar una democracia liberal:

No creo que por ahora puedan implantarse en África nuestras grandes instituciones políticas: el sistema electoral, la libertad de prensa, el jurado. Estas instituciones no son necesarias durante la primera infancia de las sociedades. En cambio, hay ciertas libertades, no reconocidas en Francia que podrían serlo sin dificultad en África. Citaré, por ejemplo, la libertad de enseñanza ${ }^{90}$.

Entre sus intérpretes, no todos han sometido la faceta colonialista de Tocqueville a críticas severas. Jardin avisa sobre el peligro de perder el auténtico sentido de sus palabras, si se las interpreta descontextualizándolas de su momento histórico concreto. Tocqueville solamente pretendería ser tan buen servidor de su país como sus antepasados más ilustres, entre los cuales destaca Malherbes $^{91}$.

\footnotetext{
89 TOCQUEVILLE, 2009: 160.

90 TOCQUEVILLE, 2009: 135.

91 JARDIN, 1962: 69-70.
} 
Sin embargo, es difícil no ver, en los textos sobre Argelia, un problema de incoherencia en los planteamientos políticos de Tocqueville. Parafraseando a Romay, «el humanista de una pieza que es Tocqueville» ${ }^{92}$, se quiebra cuando de la «ética de la convicción», cuyos axiomas derivan de la igualdad de los seres humanos y de su derecho a la libertad, pasa a la «ética de la responsabilidad», cuyo objetivo es el bien de la nación y no la adecuación a principios abstractos. Richter fue uno de los primeros autores en analizar la incoherencia del humanista liberal de La Democracia en América y El Antiguo Régimen y la Revolución con el nacionalista enfrascado en la cuestión argelina ${ }^{93}$. Utilizando una expresión no científica, pero contundente, es un analista preciso cuando ve y analiza la paja en el ojo ajeno, pero incapaz de ver la viga en el suyo.

Algunos expertos en la obra tocquevilliana han ampliado el marco de la discusión: la relación del liberalismo con el espíritu colonialista, el imperialismo subyacente en el liberalismo. Así, Todorov analiza los textos tocquevillianos a la luz de los planteamientos liberales. Desde la mentalidad liberal, hay un corte entre los derechos de los individuos y los derechos de los Estados. La libertad y la igualdad de los individuos son derechos inviolables. Pero cuando hablamos de las colectividades, de los pueblos o de los Estados, no podemos decir lo mismo: el dominio de los otros, ilegitimo, injusto e ilícito en el plano de los individuos, puede ser admisible y razonable en el plano de las colectividades. Dejemos hablar a Todorov:

Los Estados, al igual que los individuos, tienen esferas en las cuales actúan en función, únicamente de su voluntad (los derechos negativos); pero, a diferencia de los individuos, los Estados no tienen por qué conformarse con un código que les atribuya derechos positivos, por la sencilla razón de que tal código no existe. En efecto, para que el derecho se pueda ejercer, es preciso, necesariamente, que exista un espacio social en el interior del cual la colectividad pueda imponer la aplicación de la ley (éste es, precisamente, el Estado de Derecho). Ahora bien, contrariamente a lo que dejan imaginar los sueños idílicos de los enciclopedistas, no existe la «sociedad general», un espacio social universal, provisto de «gendarmes», que garanticen la aplicación de una ley planetaria. La única regla de comportamiento internacional es, pues, la libertad, es decir, la ausencia de reglas (un estado de naturaleza); lo cual equivale a decir que el único principio de comportamiento entre los Estados es el nacionalismo. La moral universal se detiene en el umbral de las relaciones internacionales ${ }^{94}$.

Solo el establecimiento de un poder mundial, que representara y buscara el bien común, vigilara su cumplimiento y castigara toda violación, podría

\footnotetext{
92 ROMAY BECCARIA, 2007: 315.

${ }^{93}$ RICHTER, 1963: 362-398. También se puede ver: LAWLOR, 1959. BAUDET, 1960: $121-131$

94 TODOROV, 1988b: 25.
} 
establecer un sistema liberal internacional. Sin este poder, los Estados, al igual que los individuos en estado de naturaleza previo al pacto social, buscan su propio interés, por encima de cualquier otra finalidad. Así, serán pacíficos o agresivos según las circunstancias, sus necesidades y prioridades. Por tanto, Todorov no encuentra contradicción alguna entre los principios liberales de $L a$ Democracia en América y la defensa de la política colonialista francesa en Argelia. Su mirada sobre Argelia será el correlato de su liberalismo político.

Pitts ${ }^{95}$ relaciona también el nacionalismo tocquevilliano con la temática general de su obra. Rotos los lazos tradicionales, el individualismo democrático aísla a los individuos. Estos se encierran en sí mismos, se preocupan únicamente de sus propios intereses y se apartan de los ideales colectivos. La empresa colonial en Argelia reanimaría el orgullo nacional y embarcaría a los ciudadanos franceses en una empresa común. Sería, pues, la herramienta perfecta para construir y enraizar una identidad nacional solida. Desde esta perspectiva, Argelia, es algo más que una conquista de unos territorios. Es la gran oportunidad de Francia para volver a ser una gran nación, para recuperar su grandeza y su protagonismo en Europa y en el ámbito mundial, para escapar de la decadencia a la que el progreso de la sociedad burguesa parece conducir.

De ahí que se haya relacionado la cuestión argelina con la llamada «cuestión de Oriente», con todo un juego estratégico para colocar a Francia en la esfera internacional. Las intervenciones del diputado Tocqueville en la Asamblea Nacional con motivo de la crisis egipcia ${ }_{2}$ prueban que la conquista de Argelia hay que situarla en un escenario más amplio.

\section{La cuestión de Oriente y su espíritu expansionista}

Es significativo que el primer discurso de Tocqueville en la Asamblea, el 2 julio de 1839, sea acerca de la cuestión de Oriente, sobre política extranjera. Francia e Inglaterra se disputaban la influencia en el área mediterránea, siendo Egipto un territorio de fricción entre ambas potencias, ya que ambas naciones intervenían en la disputa que mantenían el sultán y su vasallo, el pachá de Egipto Méhémet Ali.

En 1833, las tropas del pachá marcharon contra Constantinopla a través de Anatolia, pero las tropas y la armada rusa les obligaron a retroceder hasta Tauro. Aunque el tratado de Unkiar-Skelessi ponía al pachá bajo la tutela del zar, el pacto de Koutaieh le reconoció la posesión de Siria y de la región de Adana.

\footnotetext{
${ }_{95}$ PITTS, 2007.
} 
En abril de 1839, el sultán reanuda las hostilidades y, empujado por el embajador inglés en Constantinopla, decide invadir Siria. Aunque es derrotado por las tropas del hijo adoptivo de Méhémet, el despertar de la cuestión de Oriente preocupa a las principales cancillerías europeas y, concretamente, en Francia el gobierno presidido por el mariscal Soult, a la sazón, ministro de Asuntos Exteriores, considera peligroso, para el equilibrio de poderes y la influencia internacional de Francia, mantener una actitud neutral en el conflicto y solicita a la Cámara un crédito suplementario para la armada francesa en el Mediterráneo.

Tocqueville, trata de hacer ver a sus colegas en la Asamblea que la posición de Francia es sumamente compleja, crítica e inestable. Rusia apoya a Méhémet Ali porque le interesa el debilitamiento del imperio otomano. Por el contrario, Inglaterra es su enemigo declarado, pues le conviene que Turquía siga existiendo para evitar el dominio de Rusia, mantener una influencia directa sobre Egipto y convertir su territorio en una etapa de su ruta a la India ${ }^{96}$. Francia, por una parte, debe desear que el imperio otomano no se destruya, pero, por otro lado, Egipto tiene que permanecer en manos del pachá, pues no le conviene en absoluto a la nación francesa que caiga bajo la influencia inglesa. Por tanto, Francia no puede aliarse con ninguno de los bandos en lucha.

Ahora bien, ello no quiere decir que Francia no deba hacer nada, sino jugar astutamente en la escena política y defender exclusivamente sus intereses. En primer lugar, interviniendo directamente, si cualquier potencia europea lo hace. En segundo lugar, los franceses tomarán una posición análoga, si Rusia se cree con el derecho de aposentarse en Constantinopla o en cualquier punto de las costas occidentales de Asia.

Finalmente, propone la conveniencia de un congreso entre las potencias europeas con intereses en el Imperio otomano, es decir Inglaterra, Rusia, Austria y Francia. Tocqueville terminaba su discurso apelando a la necesidad de apoyar, en ese momento, al gobierno existente, pues, al fin y al cabo, significaba apoyar a la misma Francia. Así la monarquía, la Cámara y el propio pueblo tenían que llevar a la práctica la fuerte convicción de que Francia estaba llamada a tener un papel de protagonista en la esfera internacional ${ }^{97}$.

Sobre la misma cuestión, Tocqueville interviene de nuevo en la Asamblea el 30 de noviembre de 1840 en medio de un clima anglófobo y chauvinista. Los acontecimientos se habían precipitado: Inglaterra y Rusia firmaron un acuerdo sin Francia, al cual se adherían posteriormente Austria y Prusia. En dicho acuerdo, se comprometían estas naciones a mantener la integridad del imperio

96 TOCQUEVILLE, 1985: 258-259.

97 TOCQUEVILLE, 1985: 265. Tocqueville siempre sintió una especie de contradicción con las formas de gobierno bajo las que vivió: no era partidario de la Monarquía de Julio y se vio obligado a apoyarla por el bien de Francia, no era republicano y se convirtió en el defensor de la república ante los afanes totalitarios de Luis Napoleón. 
otomano; Inglaterra se había apoderado de la fortaleza de Saint Jean d'Acre; aunque Thiers envió una nota a Londres advirtiendo que Francia no aceptaría pasivamente la destitución del pachá, Luis Felipe se negó a apoyar cualquier actitud belicista por parte de su gobierno.

Nuestro autor, henchido de un nacionalismo sin límites, se duele, en una carta a Mill, de la actitud cobarde y sin alturas de miras del gobierno y de su príncipe, propia de la clase media, cuyo amor al bienestar y la tibieza de su corazón le arrastran a sacrificar la grandeza de Francia por una paz humillante y cobarde. Este proceder de la clase dirigente pone en peligro la estabilidad democrática y la cohesión social, favoreciendo un clima revolucionario. De alguna manera, los extremismos presentes en la cuestión de Oriente justifican la existencia de la «jeune gauche» como tercera vía que aúne la defensa de la democracia y de la libertad junto al patriotismo y la defensa de los intereses de la nación. Es decir, para el diputado Tocqueville, sin imperialismo no existe para Francia una independencia y una democracia estable y duradera ${ }^{98}$.

En este contexto, Tocqueville pronuncia su segundo discurso sobre la cuestión de Oriente. Una vez más, exige que Francia muestre y mantenga una postura de poder en el marco internacional. Resignarse a no tener ningún papel en la política internacional es aceptar caer en la dependencia de los países vecinos ${ }^{99}$.

$\mathrm{Al}$ igual de lo que ocurre en las intervenciones de Tocqueville en la Cámara sobre Argelia, también en sus discursos sobre la cuestión de Oriente aparece la tensión entre los principios liberales, tenidos en todas sus obras y discursos políticos como motores de su acción política, y un imperialismo para el que los derechos de los habitantes autóctonos de los territorios en liza no cuentan. Cuando se trata de política internacional, tras un nacionalismo francés burdamente patriotero, vemos desaparecer de nuevo al Tocqueville de La Democracia en América, escandalizado del trato dispensado por los blancos americanos a la población india y negra. Aparece el imperialista torticero, el nacionalista adalid de la grandeza de la patria. Como siempre sucede con los imperialistas a lo largo de la historia, a sus ojos, el imperialismo se le aparece como una necesidad ineludible para la independencia y la cohesión de Francia, pues no hay nada más peligroso para la estabilidad de una nación que la «paix sans gloire» ${ }^{100}$.

98 TOCQUEVILLE, 2002: 470-471.

99 TOCQUEVILLE, 1985: 290.

100 TOCQUEVILLE, 1985: 301. En el mismo sentido escribe (TOCQUEVILLE, 2002: 468) a su amigo Reeve: «Ce ne sont pas les seules passions anarchiques qui renversent les trônes, cela ne s'est jamais vu. Ce sont ces mauvais sentiments s'appuyant sur de bons instincts. Jamais le parti révolutionnaire n'eût renversé la branche aînée, si celle-ci n'eût fini par armer contre elle le parti libéral. Ce même danger reparaît aujourd'hui sous une autre forme. Le radicalisme s'appuie momentanément sur l'orgueil national blessé. Cela lui donne une force qu'il n'avait point eue».

Hispania, 2021, vol. LXXXI, n.o 267, enero-abril, págs. 129-158, ISSN: 0018-2141, e-ISSN: 1988-8368 https://doi.org/10.3989/hispania.2021.005 
Vemos, pues, como el diputado Tocqueville se separa del Tocqueville científico social, para quien la objetividad científica no equivalía a la neutralidad axiológica. Por el contrario, como hijo de su tiempo, el conocimiento de las instituciones y los procesos sociales se encaminaba a la construcción de sociedades cohesionadas, compuestas por ciudadanos iguales, libres, y con sentido de lo público. La pérdida del sentido ético, la ceguera del diputado Tocqueville al separar la moral de la política, en el altar de la grandeza nacional, le impiden ver los efectos indeseables y perversos para la propia nación de semejante actitud, cosa que, por otra parte, parece intuir, como se refleja en el siguiente texto:

Si actuamos como si para nosotros los antiguos habitantes de Argelia no fueran más que un obstáculo que hay que apartar o pisotear; si abrazamos a sus poblaciones, no para elevarles con nuestros brazos al bienestar y a la luz, sino para oprimirles y asfixiarles, la cuestión de la vida o de la muerte se planteará entre las dos razas. Argelia se convertirá, entonces, más tarde o más pronto, creedlo, en un campo cerrado, un desierto amurallado, donde los dos pueblos deberán combatir sin piedad, y uno de los dos deberá morir ${ }^{101}$.

Sin embargo, como bien señala Mélonio, el lugar que ocupan en su acción política el honor y la grandeza nacional, sus delirios imperialistas, su rechazo a los nacionalismos basados en particularismos culturales no se pueden considerar únicamente desbarres de un demócrata liberal inconsecuente. De alguna manera $_{2}$ revela la dificultad de mantener la distancia entre un patriotismo cívico, parapeto y foco de libertad, y un nacionalismo excluyente.

\section{A MOdo De CONCLuSIón}

Indudablemente, nadie puede negar una defensa férrea de la libertad, la búsqueda de la justicia y un sentido ético de la existencia en la obra de Tocqueville. Una lectura atenta de La Democracia en América, de sus escritos políticos, sin olvidar Los Recuerdos o El Antiguo Régimen y la Revolución, nos revelan sus esfuerzos para construir una comunidad política solidaria y libre, donde todos y cada uno de los ciudadanos son conscientes de que la libertad y la igualdad a la que aspiran no son posibles si no luchan, al mismo tiempo, para que el conjunto de la ciudadanía tenga iguales oportunidades y goce de una libertad semejante a la suya.

Su amor a la libertad está presente en toda su obra e impregna su pensamiento y su actividad política de sentido ético. Así se entiende que él mismo piense e interprete su obra y su actividad política como un intento de llevar a la

\footnotetext{
101 TOCQUEVILLE, 1962: 329.
} 
práctica los ideales republicanos de la Asamblea Constituyente. Fruto de esta dimensión ética de su pensamiento son los textos donde describe el racismo de la sociedad americana y/o expresa una oposición frontal a la esclavitud, como una institución inicua y odiosa, contraria a todos los derechos naturales de la humanidad e, igualmente, hace patente su rechazo a las tesis racistas, meras justificaciones inventadas por los esclavistas para justificarse.

Sin embargo, este hálito ético, esta tensión humanista, pierde fuerza cuando baja de los grandes principios y se encarna en las realidades sociales y políticas concretas. Entonces, Tocqueville, que nos ha ido mostrando a lo largo de sus escritos la ambivalencia de los fenómenos sociales y los efectos perversos de la igualdad, resulta ser él mismo ambivalente e incoherente: el filósofo político versus el diputado en la Asamblea Nacional empeñado en dar a su país un puesto de honor en la esfera internacional, el defensor de la dignidad humana versus el hombre remiso a asumir los derechos políticos y sociales de una parte de la humanidad, el moralista en América versus el imperialista y colonialista en Argelia y las colonias de ultramar.

En la tribuna de la Asamblea, Tocqueville deja de percibir al otro, al «extraño», desde la compasión, el dolor y la empatía, como lo había hecho en Estados Unidos con la población india y negra. Obsesionado por la defensa de los intereses de la nación francesa y sumido en un patriotismo mezquino y egoísta, aboga por un nacionalismo excluyente e imperialista, ya que — desde su perspectiva - Francia bien merece sacrificar la ética en nombre de la patria.

Así, el humanismo cívico, tan presente en sus escritos, se detiene ante el muro de las relaciones internacionales. Tocqueville hace de la conquista de Argelia y el mantenimiento de la esclavitud en las colonias de ultramar una finalidad patriótica. Su actitud ante la eliminación de la esclavitud en los territorios de ultramar, su posición ante la conquista de Argelia y sus intervenciones en la Asamblea sobre política exterior evidencian los riesgos morales que entraña querer compaginar un nacionalismo excluyente con un patriotismo cívico, parapeto y garante de libertad. En este sentido, Tocqueville, aunque no nos guste, también en este tema es contemporáneo nuestro, porque abre un dilema que una simple ojeada al panorama internacional de nuestras sociedades de la posmodernidad nos muestra todavía inconcluso.

Y si hablamos de coincidencia con nuestra época, hay un aspecto poco subrayado en Tocqueville que evidencia su sagacidad como analista: la unidad árabe tomará cuerpo desde una hostilidad a Occidente. Defiende la expansión colonial, pero, a su vez, es consciente de que dicha política provocará la emergencia del nacionalismo musulmán, basado en la guerra contra un enemigo común y en la exaltación de un particularismo religioso y cultural.

Esta contemporaneidad de las luces y las sombras de nuestro autor explica el redescubrimiento y le retour actual a su obra. Aunque las lecturas son muchas y muy heterogéneas, todas ellas parten del convencimiento de que 
adentrarnos en la obra tocquevilliana nos ayudará a comprender mejor los riesgos y los retos, las posibilidades y las limitaciones, los pecados y las esperanzas de nuestras sociedades de la posmodernidad.

\section{Bibliografía}

Abbé, Henri Gregoire, Des peines infamantes à infliger aux négriers, París, Baudquin frères, 1822.

Antoine, Agnès, L'impensé de la Démocratie. Tocqueville. La Citoyenneté et la Religion, París, Fayard, 2003.

Baudet, Henri, «Tocqueville et la pensée colonial du XIX siècle», en AA. VV., Tocqueville, Livre du Centenaire, París, Éditions du Centre National de la Recherche Scientifique, 1960: 121-131.

Begin, Christian, «Tocqueville et l'Algérie», The Tocqueville Review/La Revue Tocqueville, XXX/2 (Toronto, 2009): 179-203.

Benoît, Jean Louis, Tocqueville moraliste, París, Honoré Champion, 2004.

Benoît, Jean Louis, Tocqueville, un destin paradoxal, París, Bayard, 2005.

Boesche, Roger, The Strange liberalism of Alexis de Tocqueville, Nueva York, Ithaca \& Londres, Cornell University Press, 1987.

Coutant, Arnaud, Une critique républicaine de la démocratie libérale. De la Démocratie en Amérique d'Alexis de Tocqueville, París, Éditions mare \& martin, 2007.

Dion, Stéphane, «La conciliation du libéralisme et du nationalisme chez Tocqueville», The Tocqueville Review/La Revue Tocqueville, XVI/1 (Toronto, 1994) : 219-227.

Dunn Henderson, Christine, «Beaumont y Tocqueville», en Eduardo Nolla (ed.), Alexis de Tocqueville. Libertad, igualdad, despostismo, Madrid, FAES, 2007: 73-99.

Green, William, British Slave Emancipation. The Sugar Colonies and the Great Experiment 1830-1865, Oxford, Clarendon Press, 1976.

Guineret, Hervé, Tocqueville. De la guerre au colonialisme, París, Ellipses, 2007.

Jardin, André, «Tocqueville et l'Algérie», Revue des Travaux de l'Académie des Sciences morales et Politiques, 115 (París, 1962): 61-74.

Jardin, André, "Alexis de Tocqueville, Gustave de Beaumont et le problème de l'inégalité des races», en Pierre Guiral y Emile Termime (eds.), L'idée de race dans la pensée politique française contemporaine, París, Éditions du CNRS, 1977: 200219.

Jardin, André, Alexis de Tocqueville, París, Hachette, 1984.

Kahan, Alan, Aristocratic liberalism, the social and political though of Jacob Burckhardt, John Stuart Mill and Alexis de Tocqueville, Oxford, Oxford University Press, 1992.

Lawlor, Michael, De Tocqueville in the Chamber of deputies. His Views on Foreign and Colonial Policy, Washington, Catholic University of America Press, 1959.

Lerner, Max, Tocqueville and American Civilization, New Jersey, Transaction Publishers, 1994.

Losurdo, Domenico, Contrahistoria del liberalismo, Madrid, El Viejo Topo, 2007.

Hispania, 2021, vol. LXXXI, n. ${ }^{\circ}$ 267, enero-abril, págs. 129-158, ISSN: 0018-2141, e-ISSN: 1988-8368

https://doi.org/10.3989/hispania.2021.005 
Luste Boulbina, Seloua, "La colonie, mirage et réalité historique», en Le singe de Kafka et autres propos sur la colonie, Lyon, Sens Public, 2008a: 107-167.

Luste Boulbina, Seloua, «Postface», en Alexis de Tocqueville, Sur l'esclavage, Arles, Actes Sud, 2008b: 155-174.

Manent, Pierre, «Guizot y Tocqueville frente a lo antiguo y a lo nuevo», en Dario Roldán (dir.), Lecturas de Tocqueville, Madrid, Siglo XXI, 2007: 65-80.

Mélonio, Françoise, «L'idée de nation et l'idée de démocratie chez Tocqueville», Littérature et nation, 7 (Tours, 1991): 5-24.

Mélonio, Françoise, «Nations et nationalisme», en Laurence Guellec (coord.), Tocqueville et l'esprit de la démocratie, París, Presses de la Fondation Nationale des Sciences politiques, 2005: 337-356.

Pitts, Jennifer, «Liberalism and empire: Tocqueville on Algeria», 2007, disponible en: http://www.la.utexas.edu/users/chenry/civil/resources/PittsAPSA.htm

Richter, Melvin, «Tocqueville on Algeria», Review of Politics, 25/3 (Cambridge, 1963) : 362-398.

Romay Beccaria, José Manuel, «Tocqueville: humanista en América, nacionalista en Argelia», en Eduardo Nolla (ed.), Alexis de Tocqueville. Libertad, igualdad, despotismo, Ávila, FAES, 2007: 305-319.

Ros, Juan Manuel, Los dilemas de la democracia liberal. Sociedad civil y democracia en Tocqueville, Barcelona, Crítica, 2001.

Roviello, Anne Marie, «La démocratie selon Tocqueville: entre pente naturelle et art de la liberté», en AA. VV., La démocratie en questions, Caen, Presses Universitaires de Caen, 2008: 44-59.

Sánchez Mejía, María Luisa, «Los intereses de Francia: Tocqueville y la cuestión colonial», en Alexis de Tocqueville, Escritos sobre la esclavitud y el colonialismo, Madrid, Centro de Estudios Políticos y Constitucionales, 2009: XIII-XLVI.

Stokes, Curtis, «Tocqueville and the problem of Racial Inequality», The Journal of Negro History, 75/1-2 (Chicago, 1990): 1-15.

Terrén, Eduardo, «El análisis de la cuestión racial en el desarrollo de la sociología», en Eduardo Terrén (coord.), Razas en conflicto, Barcelona, Anthropos, 2002: 7-42.

Tocqueville, Alexis de, Voyages en Sicile et aux États-Unis. Oeuvres Complètes, V/1, París, Gallimard, 1957.

Tocqueville, Alexis de, Voyages en Angleterre, Irlande, Suisse et Algérie. Oeuvres Complètes, V/2, París, Gallimard, 1958.

Tocqueville, Alexis de, De la Démocratie en Amérique. Oeuvres Complètes, I/1, París, Gallimard, 1961.

Tocqueville, Alexis de, Écrits et discours politiques. Oevres Complètes, III/1, París, Gallimard, 1962.

Tocqueville, Alexis de, Écrits et discours politiques. Oeuvres Complètes, III/2, París, Gallimard, 1985.

Tocqueville, Alexis de, De la colonie en Algérie, París, Complexe, 1988.

Tocqueville, Alexis de, Mélanges. Oeuvres Complètes, XVI, París, Gallimard, 1989.

Tocqueville, Alexis de, Oeuvres, 1, París, Gallimard, La Pléiade, 1991.

Tocqueville, Alexis de, Correspondance familiale. Oeuvre Complètes, XIV, París, Gallimard, 1998. 
Tocqueville, Alexis de, Lettres Choisies. Souvenirs, París, Quarto Gallimard, 2002.

Tocqueville, Alexis de, Sur l'Algérie, París, Flammarion, 2003.

Tocqueville, Alexis de, Sur l'esclavage, Arles, Actes du Sud, 2008.

Tocqueville, Alexis de, Escritos sobre la esclavitud y el colonialismo, Madrid, Centro de Estudios Políticos y Constitucionales, 2009.

Todorov, Tzvetan, «Présentation», en Alexis de Tocqueville, De la colonie en Algérie, Bruxelles, Complexe, 1988a: 2-8.

Todorov, Tzvetan, «Tocqueville et la doctrine coloniale», en Alexis de Tocqueville, De la colonie en Algérie, París, Complexe, 1988b: 9-33.

Viellard, Marc, Contre Tocqueville, París, Le Temps Des Cerises, 2001.

Recibido: 06/06/2019

Aceptado: 11/02/2020 